\title{
Information System Monitoring Model Implemented in School Health Dental Unit
}

\author{
Bedjo Santoso $^{1^{*}}$, Triwiyatini $^{2}$, Nyoman Gejir ${ }^{3}$, Diyah Fatmasari ${ }^{4}$ \\ ${ }^{1,2,4}$ Poltekkes Kemenkes Semarang, Indonesia \\ ${ }^{3}$ Poltekkes Kemenkes Denpasar, Indonesia
}

*Corresponding Author: Bedjo Santoso, Politeknik Kesehatan, Kemenkes Semarang, Indonesia

\begin{abstract}
Background: Poor oral circumstances in children will disrupt the function and activity of the oral cavity, thus affecting the nutritional status and the impact on quality of life. More than 50 million school hours lost per year due to gum disease, which will affect the performance of children in school and later life success.
\end{abstract}

The Objective: This study aims to develop and implement the information system of oral health and prevention of oral disease as part of health promotion activities in Indonesian schools to implement the dental health program known as Unit Kesehatan Gigi Sekolah(UKGS) or School Health Dental Unit.

Method: This type of research is qualitative by design System Development Life Cycle (SDLC), through the planning stage and the analysis, design and design, system implementation, implementation and system maintenance. Data were analyzed using content analysis and system test.

Result: Based on the information needs of the program, applications of UKGS have four roles of users, consisting of 1) Ministry of health has a role to see all data contained in Indonesia, 2 Provincial Health Department has a role to look at all data provided in the coverage area of the provinces 3) Health Department has a position to see all data contained in the related city area coverage, 4) Health Center has a role to look at all data provided in the relevant health centers coverage.

Conclusion: The system is robust enough to do the monitoring and evaluation of UKGS activities.

Keywords: Information Systems, UKGS, users

\section{INTRODUCTION}

Poor oral circumstances in children and if not treated, it will disrupt the function and activity of the oral cavity to affect nutritional status and will have an impact on quality of life (Tinanoff, N. \& Douglass, 2001; Sriyono, 2011). More than 50 million school hours lost per year due to dental and oral diseases, which will impact on the performance of children in school and later life success.

Various prevention programs have been made to restrain the rate of development, reducing the prevalence and incidence of oral disease (Sheiham, 2005). In Indonesia, the oral health care of school children, organized in an integrated through health school units activities in the form of Unit Kesehatan Gigi Sekolah (UKGS) or School Health Dental Unit.
UKGS programs and oral health care to children in school still have not produced significant results evidenced that no province is free from dental caries (Ministry of Health, 2012). Bali Province has many oral health problems below the national average of $24.0 \%$, but the figure of recipient community care and treatment of medical personnel (dental nurse, dentist or dental specialist) is low only reached $38.8 \%$. The value is low for achieving the national target oral health dentally fit for sixth grade by $85 \%$. According to Sariyem (2011), Semarang which has 37 health centers spread across 16 districts, the schools received the program only reached $27 \%$ and preventive schedule of $37 \%$. The figure is relatively low either compared to the national target of $100 \%$ health promotion and preventive services $80 \%$.

Low coverage in UKGS caused no program implemented following the guidelines of the 
Ministry of Health. Health community center known as Pusat Kesehatan Masyarakat (PUSKESMAS) only do counseling, networking (oral health examination) and act as needed one time within one year of each new school (Riset Kesehatan Dasar, 2013). The reporting system is done manually at the end of the year using the form combined with the health center reports. Indicators of success of the program can be seen between the suitability of the process with the planned program, fitness for purpose, use and utilization of resources effectively and efficiently, as well as the ability to provide a guarantee to the suitability of the process and the achievement of objectives, through the harmonious control mechanisms in a single system. One system to monitor the activities UKGS is in the form of software operated in a monitoring information system. The purpose of this research is to develop a Monitoring Information System Dental School Care as a means of monitoring and evaluation of UKGS programs.

\section{METHODS}

The research is qualitative on application of a web-based application and system development methods (Nazir, 2014) applied to the development of UKGS application consisting of several stages of planning and analysis system of user needs (Pressman, 2010). The design and system design is the stage design and design of UKGS application from the user interface (view) or the flow path of the application. Implementation of the system is the implementation phase of the plan and the design results in the form of web-based applications. Implementation of the system is a stage of UKGS implementing application in the user environment (Health Community Center). Care system is a stage of UKGS application if there are errors in the technical and non-technical terms contained in the application (Shelly, 2012).

Step analysis of the data is divided into two stages: problem identification and UKGS data analyzed by content analysis which concludes the investigation by the respondents' answers. Black box testing is to see input and output that will be generated as well as testing white-box is to know the flow of test case they see the logical complexity of procedural design contained in the system.

\section{RESUlTS \& DISCUSSION}

Data collection is also done through the study of government policies on UKGS as stated in the decision of the Directorate General of Health Efforts No. HK.02.04 / II / 963/2012 on UKGS.

Table1. Long-Term Target Description Dental and Oral Health Ministry of Health

\begin{tabular}{|c|c|}
\hline Year & target \\
\hline 2020 & $\begin{array}{l}\text { 1. figure caries-free (mixed gear) } \leq \text { six } \\
\text { years old } 50 \% \\
\text { 2aries-free Numbers sixth grade } \geq \\
70 \% \\
\text { 3. DMF-T age } 12 \leq 1 \\
\text { 4. PTI }=50 \% \\
\text { 5. the figure is dentally Fit } 6 \text { th grade } \geq \\
85 \%\end{array}$ \\
\hline 2030 & school-age children free of dental caries \\
\hline
\end{tabular}

Based on the information needs of the program, UKGS Monitoring information System has four roles of users, consisting of 1) User Minister of Health has a position to see all data contained in Indonesia, 2) User Provincial Health Department has a part to look at all data provided in the coverage area of these provincial 3) User Health Department has a role to see all data contained in the related city area coverage, 4) User Health Center has a position to look at all data provided in the relevant health centers coverage ( Dharwiyanti, 2003).

1. The task on each user's role is: 1) Health Center: to perform data input schools, student data, execution data UKGS, the data results of the examination and treatment UKGS on students, and see recap UKGS for every school in every year, 2) User Municipal Health Office: to see UKGS recaps for every health center in the city relating to each year, 3) User provincial Health Department: to see recap UKGS of every town in the province each year connected, 4) User Minister of Health : to see recap UKGS for each province in each year

Each menu has different display depending on users role

\section{Community Public Health data}

1) Login as $\mathrm{MoH}$ will appear the registered Community Public Health or Puskesmas in Indonesia, where users can add, edit, and delete Puskesmas in the data displayed.

2) Login as Provincial Health Officer will display health centers in the province where users can add, edit, and delete puskesmas in the data shown.

3) Log in as the City Health Officer associated clinics in the city where users can add, edit, 
and delete puskesmas in the data displayed where users can add, edit, and delete puskesmas in the data displayed.

\section{SCHOOL DATA}

1) Login as MoH will appear the list of schools in Indonesia where users can add, edit, and delete the displayed school data.

2) Login as PHO will appear school list contained in the relevant province where users can add, edit, and delete the displayed school data.

3) $\log$ in as the City Health Officer will appear the list of schools located in the region concerned where users can add, edit, and delete the displayed school data.

4) Log in as Community Public Health will appear school list contained in the relevant health centers where users can add, edit, and delete the displayed school data.

\section{Student Data}

1) Login as $\mathrm{MoH}$ will appear the list of schooling students in Indonesia where users can add, edit, and delete the displayed student data.

2) Login as PHO will appear the list of students who are in schools in the province concerned and can add, edit, and delete data, such students.

3) $\log$ in as the City Health Officer will appear the list of students in schools in the region concerned and can add, edit, and delete data such students.

4) Log in as PHC: Appears the list of students who are in schools in the region related to the health center where users can add, edit, and delete the displayed school data.

Implementation of UKGS will contain information on inspection and maintenance carried out by the health center on students.

1) Login as MoH will appear list of UKGS inspection and maintenance carried out by the health centers to students in Indonesia.

2) Login as PHO will appear list of UKGS inspection and maintenance carried out by the health centers to students in the province concerned.

3) $\log$ in as the City Health Officer will appear list of UKGS inspection and maintenance carried out by the health centers of the students in the region concerned.
4) Log in as Community Public Health will appear list of UKGS inspection and maintenance carried out by the health centers to students in the region related to the health center.

Recapitulation contains information on implementation, inspection, and enforcement of UKGS conducted by the health center.

1) Login as $\mathrm{MoH}$ will appear recapitulation of implementation, inspection, and enforcement of UKGS implemented by the health center in the area of Indonesia. The main recapitulation is displayed by provinces.

2) Login as PHO will appears recapitulation of implementation, inspection, and enforcement UKGS implemented by health centers in the province related. The main recapitulation is shown based on city.

3) Log in to as City Health Officer will appear recapitulation of implementation, inspection, and enforcement UKGS implemented by health centers located in the region concerned. The main recapitulation displayed based according to the health center.

4) Log in as Community Public Health will appear recapitulation of implementation, inspection, and enforcement UKGS implemented by the relevant health center.

\section{CONClusion}

Through the Monitoring Information System for School, Dental Health Unit can be monitored and evaluated the activities of UKGS at the health center, the City Health Office / District and Provincial Health Office and the Ministry of Health. Therefore the Ministry of Health is recommended order to make UKGS as the principle in the health centers and the utilization of significant funds for UKGS activities.

\section{REFERENCES}

[1] Dharwiyanti, Sri 2003. "Introduction to the Unified Modeling Language (UML)".

[2] Nazir, M., 2014. Research Methods. Ghalia Indonesia, Jakarta.196-215.

[3] Pressman, Roger S. 2010. Software engineering. A Practitioner's Approach. Seventh Edition.Higher Education.

[4] Riset Kesehatan Dasar, 2013, Badan Penelitian dan Pengembangan Kesehatan Kementerian Kesehatan

[5] Sariyem 2011. Analysis of Program Implementation UKGS in Promotive and 
Preventive Services at the Work Area Health Center Semarang City Health Office. Thesis MasterIKM Diponegoro University

[6] Shelly, GB. 2012. Discovering Computers, Salemba Infotek, Jakarta.

[7] Sheiham, A. 2005. Oral Health, General Health And Quality of Live, Bulletin of the World Health Organization, September,83 (9); 641720.
[8] Sriyono, W. 2011. Dental and Oral Disease Prevention to Improve the Quality of Life. Material Master Besar.FKG inaugural UGM. Yogyakarta.

[9] Tinanoff, N. And J.M. Douglass. Clinical Decision-Making for Caries Management in Primary Teeth. J Dent Educ. 2001; 65(10): 1133-1142.

Citation: Bedjo Santoso, Triwiyatini, Nyoman Gejir, Diyah Fatmasari. Information System Monitoring Model Implemented in School Health Dental Unit. ARC Journal of Dental science. 2017; 2(4): 8-11. doi:dx.doi.org/10.20431/2456-0030.0204003.

Copyright: (C) 2017 Authors. This is an open-access article distributed under the terms of the Creative Commons Attribution License, which permits unrestricted use, distribution, and reproduction in any medium, provided the original author and source are credited. 